\title{
CONSERVATION STRATEGIES IN A CHANGING WORLD
}

\author{
DOMINIQUE BACHELET
}

Conservation Biology Institute, 136 SW Washington Avenue, Suite 202, Corvallis, OR 97333. E-mail:dominique@consbio.org

\begin{abstract}
Despite the scarcity of sustained funding to promote continuous record collection, scientists and citizens around the world are now generating large volumes of monitoring data that vary in quality, format, supporting documentation, and accessibility. Complex interactions between climate, fauna, flora, and human land use challenge the understanding and forecasting of the mechanisms of change. Diverse models are now being run at various spatial and temporal scales to understand past climate variability and its impacts, generate future climate and land use scenarios, and project potential future impacts to the planet's inhabitants. Estimates of the uncertainty associated with past observations and climate proxies, and with the results from climate and climate impacts models, are often discussed but rarely quantified in a useful way to help land managers. Ultimately, social choices and political decisions hold the keys to the future in terms of emissions, land use (agriculture, urbanization, industrialization, energy resource acquisition), and conservation efforts. Conservation practitioners and land managers are struggling to synthesize the wealth of available information and heed warnings of the unpredictable human response to change. They have to identify the relevant and usable datasets, become aware of gaps in knowledge and information, and translate evolving science results into on-the-ground climate-aware strategies. Many agencies and NGOs are currently involved in synthesizing observations and simulations, developing land management strategies, and implementing those they judge are most likely to succeed or at least cause the least harm. Collaboration and effective information sharing is essential to work effectively towards common goals. This paper includes examples of sources of climate change information, a brief summary of the types of models currently used in climate change science projects, and illustrations of collaborative efforts that address climate change issues specifically focused on the Gyrfalcon in panarctic regions. Received 8 August 2011, accepted 19 September 2011.
\end{abstract}

BACHELET, D. 2011. Conservation strategies in a changing world. Pages 385-398 in R. T. Watson, T. J. Cade, M. Fuller, G. Hunt, and E. Potapov (Eds.). Gyrfalcons and Ptarmigan in a Changing World, Volume II. The Peregrine Fund, Boise, Idaho, USA. http://dx.doi.org/10.4080/gpcw.2011.0317

BaChelet ET AL. (2005) USED the Dynamic Global Vegetation Model (DGVM) MC1 to project what climate change might mean in terms of vegetation distribution, carbon storage or emissions, and wildfire risk in Alaska. The results pointed toward significant changes to arctic ecosystems with $77-90 \%$ of the tundra present in Alaska in 1920 possibly disappearing by the end of the $21^{\text {st }}$ Century. Interior boreal mixed forests could migrate northward, creating maritime and temperate conifer forests much like those of southeast Alaska. 
The "woodification" of the entire state would greatly increase the potential extent of the area burned by wildfires. More recently, Feng et al. (2011) used 16 more recent future climate projections in the Köppen-Trewartha climate classification method and projected a 33 to $44 \%$ decrease in tundra extent (from current) by the end of the century, accompanied by a northward shift of coniferous forests and needle-leaf trees. Field observations are now also supporting the model results. Beck et al. (2011) use tree ring data and satellite information to show evidence of growth increases at the boreal-tundra ecotone in contrast with drought-induced productivity declines throughout interior Alaska. The Arctic Council's working group for environmental monitoring (the Arctic Monitoring and Assessment Programme) substantiated the increased warming in the Arctic, with warmer summers and shorter winters, increased melting of the icecap, and declining snow cover driving negative albedo feedbacks, confirming what models had projected: the arctic environment is changing fast (AMAP 2011). Gyrfalcons and their principal prey, ptarmigan, which are widely distributed in the Arctic, will likely be significantly affected by these projected changes to their habitats and food sources. This paper includes a brief discussion of the climate change information available, a quick summary of the types of models currently used in climate change science, and introduces collaborative efforts that address climate change issues specifically focused on the Gyrfalcon in panarctic regions.

\section{Climate Change Information Available}

Changes in arctic ecosystems associated with recent climate change have been rapid and widespread across terrestrial, freshwater, and marine systems (Post et al. 2009). Modelers try to capture both changes in climate and in ecosystems responses and better simulate potential trends in those changes, allowing local populations and land managers to prepare for what comes next. However, despite recent efforts to gather extensive datasets for the region to test the models, long-term data are lacking and existing data include some uncertainty due to the remoteness and sparse population monitoring change.

Climate Records.-Climate records are used by climate modelers to test and calibrate their models, using subsets of the full dataset to do so. When data are scarce, models are less likely to produce robust representations of current conditions, let alone project realistically into the future. Around the Arctic Circle, there are few meteorological stations, so historical climate data sets are very limited and interpolations between meteorological stations may provide uniform maps of climate but their uncertainty is large. Measurements of climate variables are difficult per se: there is much heterogeneity on the landscape that may not be captured by a sparse meteorological station network, so eventually the reliability of climate models trying to simulate such patterns suffers. The length of records from meteorological stations may also vary. The age of a station is of course the main cause for the differences in record length between stations. Less obvious is the amount of "in-filling" performed to remove gaps in data collections. Gaps in data records can be caused by an instrument that has stopped working, some disturbance to the equipment, or even a complete change of station instrumentation. In-filling can be done by using data from the closest meteorological station using the correlation between station records, and using those to complete the dataset assuming weather records continue to be correlated through time. When only a few days are missing, a simple linear interpolation between days can also be used to complete the record.

To illustrate the problem of the spatial distribution of meteorological stations and their variable length of records in the Arctic, Figure 1 shows the density of long-term meteorological stations in North America (Groisman et al. 2005). The red stations have about 100 years worth of records, the blue stations have about 80 years, and the green stations have in gen- 
eral, more than 25 years including the 19611990 period which has been used extensively as a baseline in modeling. Alaska and northern Canada have relatively few meteorological stations providing climate information. This means that every gridded climate map for northern latitudes corresponds to multiple interpolations over large areas that include few stations. There are multiple ways to deal with this problem. For example, NASA and the Goddard Institute of Space Studies climate modeling group fill gaps using records from the nearest stations and provide wall-to-wall maps of climate (http://www.giss.nasa.gov/ research/news/20110113/509984main_201111 _anomaly_maps.jpg). The Climate Research Unit (UK Meteorological Office) leaves out the regions where there is scarcity of meteorological data. They thus provide incomplete maps but there is definitely legitimacy in doing this to make people more aware of data gaps and the challenge for climate modelers to test their models against historical observations. As a result it is very difficult to look at natural climate variability when the actual length of the records is limited and in-filling has been used extensively. However, the variance around the mean and the amount of extreme temperature or precipitation events are much needed to test model sensitivity to climate and identify climate thresholds.

Gaps in Knowledge.-Not only are there gaps in information, there are also gaps in knowledge about climate dynamics in climate models. Clouds, aerosols, and deep-ocean dynamics are still subjects for research by climate modelers. Moreover, variable land use may affect climate and is difficult to predict in the future. While urban heat island effects were found to have minimal impacts on global climate (Parker 2006), feedbacks from irrigated areas could have affected $20^{\text {th }}$ Century temperature trends and monsoon intensity (Puma and Cook 2010). Aeolian dust caused by destabilization of dry soils, often through human land use (agriculture, overgrazing, off-road vehicle use, road and housing developments), can affect the atmos-

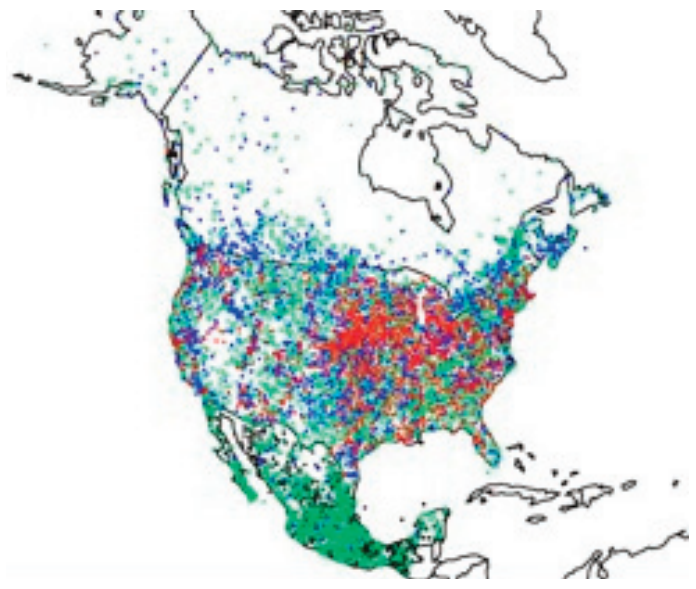

Figure 1. Density of long-term meteorological stations in North America. Source: Groisman et al. 2005. [permission from Pavel Groisman] Present coverage of North America south of $55^{\circ} \mathrm{N}$ with long-term (at least 25 years of data) stations. Red and blue dots show stations with $\sim 100$ and 80 years of data, respectively. Green dots indicate stations with at least 25 years of data during the 1961-1990 period. Black dots show additional long-term Mexican stations that are presently underoing extensive quality control.

pheric radiation budget and create cloud condensation nuclei while its deposition increases the melting rate of snow and ice (Okin et al. 2011). These feedbacks from the earth's surface to the global atmosphere are either lacking or extremely simplified in most global climate models. Furthermore, teleconnections, such as ENSO, the El Nino Southern Oscillation index, the PDO, Pacific Decadal Oscillation, the NAO, the North Atlantic Oscillation, are indices of the natural climate variability related to changes in sea surface temperature and can be tracked, but what causes their shift from one phase to the other is often unknown and the subject of ongoing research.

Consequently, general circulation models (GCMs) that represent the synthesis of the current understanding of how our planet's climate system works, continue to be developed and increase in complexity as our knowledge and understanding of atmosphere-ocean-soil-plant- 
human systems interactions and feedbacks increases. When the first assessment report from the Intergovernmental Panel for Climate Change (IPCC) was published in 1990, the representation of the oceans in global climate models was very simple, a single layer. By 1995 for the $2^{\text {nd }}$ assessment, multiple layers had been added to simulate ocean dynamics, and the feedbacks from anthropogenic sulphate emissions were included. By 2001 the effects of multiple aerosols had also been included and by 2007 vegetation feedbacks to the climate system had been significantly developed. These are not simple changes to large models, and each new IPCC report summarizes our current state of knowledge and understanding of our planet's climate dynamics, synthesized in those climate models. As humans continue to emit greenhouse gasses into the atmosphere, we have the unique opportunity to record their impacts on local and global climate patterns, and adjust our models. Because human emissions have never reached current levels before, new information needs to be constantly gathered to enhance scientific understanding of the on-going changes.

Spatial Scale.-The scale of GCMs has decreased from $\sim 500 \times 500 \mathrm{~km}$ grid cells in 1990 to $\sim 110 \times 110 \mathrm{~km}$ grid cells in 2007, although the question remains: at what scale do we measure and understand climate processes and at what scale are interpolations most reliable (Wiens and Bachelet 2010)? GCM projections cannot be used directly for regional or local impact assessments because GCMs were designed to simulate the entire planet's climate and their accuracy declines at the local scale due to their inherent coarse spatial resolution. Even the finer scale of regional climate models (RCMs) $(\sim 15 \mathrm{~km})$ remains fairly coarse for biologists who deal with cliff nest sites, for example. However, to run climate models, much information is required for every grid cell or pixel, and data needs are not easily met. In complex terrain, such as cliffs, deep valleys, and rugged mountains, the local climate may decouple from regional climate and create local processes that are difficult to measure, let alone simulate by climate models (Daly et al. 2009). Cold air drainage in valleys, temperature inversions, fog banks along large bodies of water, all feed back to the atmosphere but their measurements and representations in models are far from simple.

Researchers must therefore downscale (statistically or dynamically) the original global climate model results to their grid size of interest (Wilby et al. 1998, Diez et al. 2005). Downscaling coarse-scale climate information is now widely used by biologists and land managers to obtain fine resolution climate information that may be used for vulnerability assessments. The easiest way to downscale is the "delta method," in which the difference (or ratio for precipitation) between future and current GCM results, called the delta, is calculated and added (or multiplied) to a "baseline" or observed long-term average climate (19611990 or 1971-2000) in order to generate a future climate data set. It is important to remember when using these data that, despite the fact that the information is now served at a fine scale, the original climate change information was generated at a coarse scale and did not take into account feedbacks from local processes, assuming coarse scale homogeneity of land cover. Another method is called statistical downscaling and uses a bias correction that minimizes the difference between the GCMs hindcast of historical conditions and observations. Future projections are corrected with this calculated bias, assuming that the correlation between GCM results and actual climate patterns will not change in the future. This assumption is important to remember when future climate scenarios are being used in land management decisions. The third and most recent method is dynamic downscaling that uses an RCM run at a finer spatial scale including local climate patterns. RCMs incorporate local topography and land-atmosphere feedbacks, and are the most mechanistic way to simulate regional to local climate variables. RCMs include boundary conditions that come 
from the general circulation models, so their reliability is also linked to that of the GCMs and any bias in GCM results will automatically carry to the embedded RCM. Currently, research teams are working on allowing feedbacks from local climate processes (simulated by the RCM) to the GCM, a process that is still lacking (Rummukainen 2010). Despite their superior skill at simulating local weather, RCMs have large computing and data storage requirements, so often only short time periods rather than full time series of results are saved, resulting in limited temporal extent of the available data (e.g., North American Regional Climate Change Assessment Program, http://www.narccap.ucar.edu/). RCMs tend to also remain too spatially coarse for management needs (Fowler et al. 2007).

\section{Climate Change Projections and the Ensemble} Approach.-Although GCMs and RCMs are becoming better at simulating present-day climate (Reichler and Kim 2008), their wide range of future projections introduces a large degree of uncertainty to ecosystem impact assessments. Because climate models are very sensitive to initial conditions, modeling teams sometimes provide results using the same model but with different starting points, as an ensemble of projections: each of these projections is equally plausible. Clearly, when looking for likely future climate projections, models that have simulated past climate well when compared with observations are preferred. However, the accuracy of a climate model to reproduce the past relates to the model's explanatory power but not its predictive power. Ultimately, no model is a crystal ball. At best, one can conclude that if a model can simulate the past well, assuming that most processes will not change, the model will do a good job projecting the future.

Clearly, fossil fuel emission scenarios derived from potential demographics and assumed societal choices are the major source of uncertainty associated with GCM projections because of our inability to forecast future human behavior changes (Table 1). To bracket all possible changes IPCC reports present ensembles of GCMs over a wide range of emission scenarios. These ensembles provide an estimate of the range of potential future conditions simulated by only about 20 research groups around the world and in truth, future climate is not necessarily bound by those projections. As change occurs today and continues to do so (e.g., icefree poles, glacier retreat and disappearance, new wind patterns, changes in ocean temperature and current direction, increasing atmospheric carbon dioxide concentration), some of the basic assumptions at the core of the climate models may become obsolete and the future may lie entirely outside of the envelope that climate modelers have so far provided (Raisanen 2007). Ensemble means have been described as the most reliable source of future projections (e.g., Giorgi and Mearns 2002, Gleckler et al. 2008) but what does it mean to average models that simulate the Arizona monsoon for example with others that do not?

\section{Climate Change Impacts}

Ecological forecasting is relatively new (e.g., Clark et al. 2001, Araújo and New 2007). While climate modelers have been very organized and always presented their result as ensembles of approaches and scenarios, ecologists have mostly worked in independent teams, rarely involving comparisons of multiple model approaches. There are notable exceptions where biogeochemistry models or dynamic global vegetation models have been subjects of comparisons, mostly focused on the carbon budget of forests (Cramer et al. 2001, McGuire et al. 2001, Bondeau et al. 1999, Amthor et al. 2001).

Climate Change Impacts Models._Modeling studies have predicted that climatic shifts will cause large changes in the dominant vegetation types at high latitudes (e.g., Scholze et al. 2006). Most studies have used global biogeography models or dynamic global vegetation models (DGVMs) that capture changes in 
Table 1. Emission scenarios used for AR4 (IPCC 2007) with information extracted and simplified from N. Nakicenovic et al. (2000), as well as brief description of the emission scenarios to be used in AR5 (Moss et al. 2010). Climate models are being run and average changes in temperature and precipitation remain to be estimated across all the models that will be included in the next IPCC report.

\begin{tabular}{|c|c|c|c|c|}
\hline $\begin{array}{l}\text { SRES emission } \\
\text { scenarios used } \\
\text { for AR4 (2007) }\end{array}$ & Description & $\begin{array}{l}\text { CO2-equiv. in } \\
\text { ppm by } 2100\end{array}$ & $\begin{array}{l}\text { Temperature } \\
\text { change in } \\
\text { deg. } \mathbf{C}^{a}\end{array}$ & $\begin{array}{l}\text { Sea level } \\
\text { rise in } \\
\text { meters } \\
\text { (conservative) }\end{array}$ \\
\hline $\mathrm{A} 1 \mathrm{~B}$ & $\begin{array}{l}\text { Rapid economic growth, global } \\
\text { population peaks mid-century ( } 9 \text { billion } \\
\text { in 2050), rapid introduction of new and } \\
\text { more efficient technologies: balance } \\
\text { across all energy sources }\end{array}$ & 850ppm & $1.7-4.4(2.8)$ & $0.21-0.48$ \\
\hline A1T & $\begin{array}{l}\text { Rapid economic growth, global } \\
\text { population peaks mid-century ( } 9 \text { billion } \\
\text { in 2050), rapid introduction of new and } \\
\text { more efficient technologies: non-fossil } \\
\text { energy sources }\end{array}$ & 700ppm & $1.4-3.8(2.4)$ & $0.20-0.45)$ \\
\hline $\mathrm{A} 1 \mathrm{FI}$ & $\begin{array}{l}\text { Rapid economic growth, global } \\
\text { population peaks mid-century ( } 9 \text { billion } \\
\text { in 2050), rapid introduction of new and } \\
\text { more efficient technologies: } \\
\text { fossil-intensive }\end{array}$ & 1550ppm & $2.4-6.4(4.0)$ & $0.26-0.59$ \\
\hline B1 & $\begin{array}{l}\text { Global environmental sustainability, global } \\
\text { population peaks mid-century ( } 9 \text { billion in } \\
2050 \text { ), service and information economy, } \\
\text { introduction of clean and resource-efficient } \\
\text { technologies }\end{array}$ & \%60ppm & $1.1-2.9(1.8)$ & $0.18-0.38$ \\
\hline A2 & $\begin{array}{l}\text { Regionally oriented economic } \\
\text { development, continuously increasing } \\
\text { population ( } 15 \text { billion people in } 2100) \text {, } \\
\text { slow technological change }\end{array}$ & 1250ppm & $2.0-5.4(3.4)$ & $0.23-0.51$ \\
\hline B2 & $\begin{array}{l}\text { Local environmental sustainability, } \\
\text { continuously increasing global population } \\
\text { (more than } 10 \text { billion people in } 2100 \text { and } \\
\text { rising), slow but diverse technological } \\
\text { change }\end{array}$ & 800ppm & $1.4-3.8(2.4)$ & $0.2-0.43$ \\
\hline Commitment & No change in $\mathrm{CO} 2$ concentration & $\sim 380 p p m$ & & \\
\hline $\begin{array}{l}\text { RCP } 8.5 \text { to be } \\
\text { used for AR5 } \\
\text { (2013) }\end{array}$ & no stabilization & $>1,370 p p m$ & & \\
\hline RCP 6.0 & stabilization after 2100 & 850ppm & & \\
\hline RCP 4.5 & stabilization after 2100 & $\sim 650 \mathrm{ppm}$ & & \\
\hline RCP 2.6 & Peaks before 2100 and then declines & $\sim 490 p p m$ & & \\
\hline
\end{tabular}

SRES = Special Report on Emission Scenarios

$\mathrm{RCP}=$ Representative Concentration Pathway

a 2090-99 relative to $1980-99$

References: IPCC 2007, Moss et al. 2010, Nakicenovic et al. 2000, 
plant functional types and associated carbon budget, nutrient, and energy fluxes, as atmospheric $\mathrm{CO}_{2}$ concentration increases and affects their physiology. These models only coarsely describe plant community structure without any consideration of species assemblages (e.g., Bachelet et al. 2001, Scholze et al. 2006). Consequently, they are mostly inadequate for examining biodiversity issues focused on species richness, but they are useful to describe climate impacts on ecosystem services (carbon sequestration, water availability) as well as the role of climate-driven shifts in disturbance regime on ecosystem function.

Species distribution models (also called niche models, bioclimatic, envelope models) vary substantially in their ability to predict current species distributions and produce highly variable predictions of species range shifts under changing climate (Araújo and Rahbek 2006, Elith et al. 2006, Pearson et al. 2006). Because they are based on correlations between current environmental conditions and species range, the validity of the models relies on these interactions remaining constant in the future (Rehfeldt et al. 2006). They mostly ignore nonclimatic drivers such as biotic interactions, which may be critical and highly variable in the future (Wiens et al. 2009). Finally, these models are snapshots that do not take into account the trajectory between current and future conditions. For example, a niche model can project that, 20 years from now, conditions will be perfect for a particular species, but that species may have died 10 years before from an extreme event. Abrupt changes caused by extreme events have been measured in the past: the numbers of returning spring Chinook Salmon (Oncorhynchus tshawytscha) measured in the Methow River in Oregon showed around 1977 a total collapse from about 20,000 individuals to about 2,000 due to an ocean regime shift (Figure 2). Ocean regime shifts are part of the natural climate variability and can have large impacts inland, affecting for example the frequency and extent of wildfires (Littell et al. 2010), and ultimately affecting

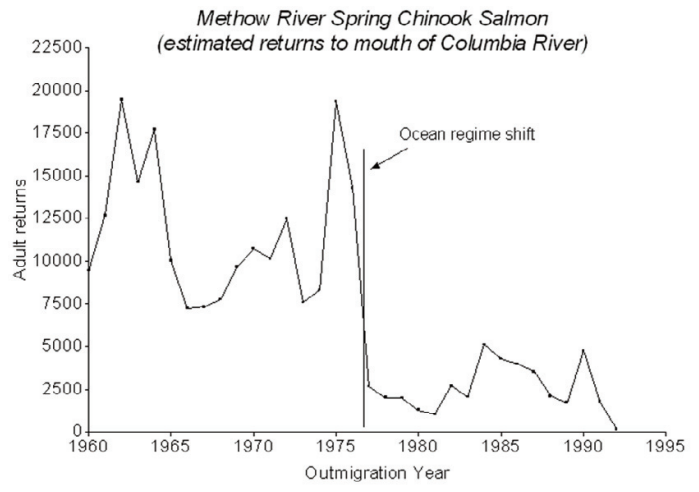

Figure 2. Wild spring Chinook Salmon returns to the mouth of the Columbia River by year of outmigration. Source: Fish Passage Center (http://www.fpc.org/).

species survival. Niche models, because they are static, do not include the influence of natural climate variability on species range nor can they simulate how changes in this variability will affect range shifts.

Many physiological responses to climate change in present-day species or ecosystem dynamics are interpreted as consistent with loss of biodiversity, declines in ecosystem services, and insufficient time for substantial evolutionary responses. Emerging evidence from the variability of genotypes and species responses (Nicotra et al. 2010), geographic variation in susceptibility and recovery from disturbance (Pandolfi et al. 2011), response to past climate change (e.g., Ackerly 2003), and potential rates of adaptation to rapid warming supports alternative scenarios in which greater temporal and spatial heterogeneity exists than current projections suggest. Current models tend to ignore the capacity of plants and animals to adapt or acclimate to new conditions. Consequently, existing projections of changes (particularly extirpation) in species extent are subject to uncertainty and should be regarded as suggestions based on current state of models rather than predictions. 
Uncertainty in Climate Change Impacts.Uncertainty in climate change impacts can be due to the impacts of model structure and assumptions added to the uncertainty inherent in the climate information used. Scientists at the California Academy of Sciences (Healy Hamilton and Michel Fernandez, article in prep.) have created an index of uncertainty to accompany the climate input data used in their niche models. This uncertainty index is based on agreement between climate models (more agreement, less uncertainty), complexity of the terrain (more complex terrain, more uncertainty), density of the meteorological stations (dense network, less uncertainty), climate variability (standard deviation of the models, more variable more difficult to simulate), and others such as proximity of human population centers (urban heat island) or proximity to the coast/large body of water (fog banks effect). In the literature, confidence in the location and extent of the areas of change may be based on the degree of agreement between GCM model projections (e.g., Gonzalez et al. 2010, Klausmeyer and Shaw 2009), assuming that if different approaches converge on one solution (a particular level of warming or magnitude of precipitation) the outcome is more likely. In fact, models can agree for the wrong reason. More importantly, ignoring areas where climate models disagree may translate as missing opportunities where mitigation strategies might be effective, where climate refugia might exist on a landscape too complex to warrant a single set of assumptions.

Disturbance testing was used in the early 1980 s to determine whether a model was stable or chaotic after a disturbance of variable magnitude and duration. When data exist on an ecosystem response to a disturbance (e.g., removal of a predator, doubling of grazing levels, doubling of summer precipitation) the model response can be tested against observations to confirm that the model includes enough information to mimic the natural response. When models include thresholds, sensitivity analyses can reveal how far from those thresholds current conditions are and how much they need to be modified to cause a shift in ecosystem response, an index of the simulated system vulnerability to change. For example, we looked at a dynamic vegetation model response to precipitation when precipitation variance was either doubled or halved (Figure 3). When simulating a shrubland system in eastern Oregon, grasslands can emerge from a doubling of the variance in rainfall rendering water availability too variable to sustain woody lifeforms, while a forest can develop when the rainfall variance is halved, allowing for tree establishment.

An alternative to acquiring a set of future climate projections to run impacts models would be to first obtain from the climate modeling teams the probability of each climate variable's level of change. These would include for example a doubling in variance for precipitation, or the likely occurrence of two consecutive summers with temperatures $5^{\circ} \mathrm{C}$ above current maximum summer temperature). Then, the sensitivity of the impacts model would be tested to those various levels that might cause ecosystem shifts, thus quantifying their risk of occurrence in the future.

\section{“Climate-SmarT" Conservation Strategies}

Explicit conservation goals or visions are needed to assess conservation strategies and measure their eventual success (or failure) in the face of climate change (Thorpe and Stanley 2011). Numerous principles have been put forth for successful conservation but many, including some of the most widely cited (National Park Commission, http://www.npca. org/commission/), are based on static visions of returning to historic conditions. Climate change projections, on the other hand, emphasize a high likelihood of vegetation shifts and altered community composition, possibly including novel species assemblages without any historical or contemporary precedent. While understanding the ecological history of a place can help shape a vision for conserva- 
Location:

Redmond, OR
Historical Precipitation Variance

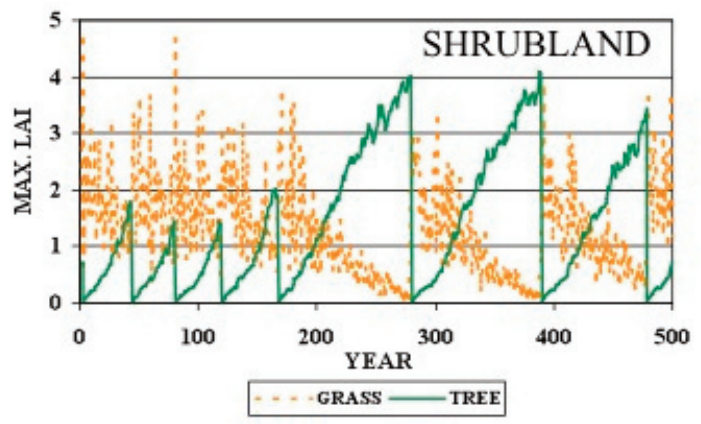

Grass LAI

Tree/Shrub LAI
Precipitation Variance $\mathrm{x} 2$

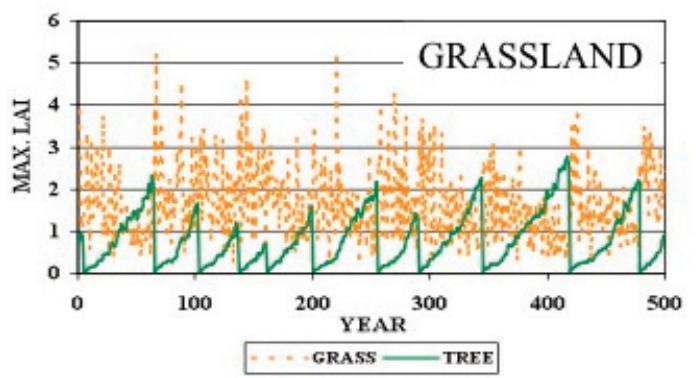

Precipitation Variance / 2

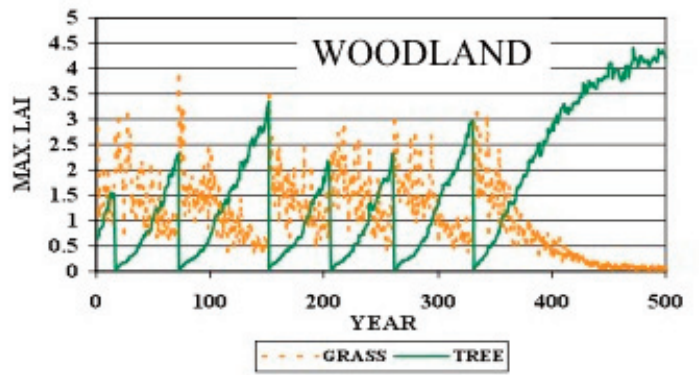

Figure 3. Impacts of a change in precipitation variance on simulated vegetation cover (MC1 simulation) and fire return interval in Redmond, Oregon. The graph shows the dynamics of the two existing lifeforms, herbaceous and woody. When precipitation variance is halved and there is a reliable source of available water, the woody lifeform eventually dominates, and woodland, later forest, becomes established. When the variance is doubled, only grasslands can cope with erratic water availability and dominate the landscape.

tion success, one of the greatest contributions climate change discussions have brought to the conservation community is an appreciation of the dynamic nature of natural systems. Any static vision will likely fail in the face of climate change.

Cross et al. (submitted 2011) designed a framework called Adaptation for Conservation Targets (ACT) to identify practical "climate-smart" management actions for particular locations, species, or ecosystems. The approach is based on the premise that effective climate change adaptation can be more reliant on local managers' and scientists' knowledge of the ecosystem in question than on detailed projections of climate change. It is an iterative process, as steps can be repeated to accommodate changes in management and social priorities, ecological information, and climate trajectories. The iterative process alleviates the pressure to consider the full complexity of a system all at once, and helps users overcome the uncertainty paralysis associated with projected future climate changes and impacts. I have tried to illustrate the value of the ACT Framework to address natural resource management decisions specifically focused on Gyrfalcons in arctic regions based on the information I gathered during the conference. My goal is to show how one could initiate adaptation planning, eventually generating and com- 
municating specific management interventions that could maximize conservation effectiveness of Gyrfalcons under an increasingly altered, yet uncertain, climate.

First, it is important to identify the ultimate goal or management objective for this exercise. In this case I have identified several possible goals: the ultimate survival of the Gyrfalcon species, the conservation of Gyrfalcon genetic diversity, the protection of sustainable Gyrfalcon population levels, and/or the continued success of Gyrfalcon reproduction. Secondly, it is necessary to build a graphical conceptual model that summarizes the state of knowledge about the system and illustrates the climatic, ecological, social, and economic drivers around the goal. Conceptual models rely on local knowledge, and participation by relevant experts in adaptation planning helps ensure that the most important drivers are identified. Primary drivers for Gyrfalcons include climate (snowpack, temperature, rainfall), natural disturbance (storms, floods, drought, fire), human activities (pollution, hunting, poaching, resource extraction). These drivers interact and can exacerbate each other's impacts; for example poaching can decimate a population that has already been reduced by stressful climate conditions in a particular year. Secondary drivers include habitat such as rocks or trees that provide nesting habitats, sea ice extent which affects the food chain and the phenological events in the system, soil permafrost which affects available soil water and temperature, vegetation which affects food sources, fire risk, shelter, and prey. Other levels of the food chain can be included such as competitors (e.g., Peregrine Falcon Falco peregrinus, eagles) or predators (e.g., bears). Such a conceptual model summarizes the knowledge of local experts, scientists, and managers familiar with the system of interest, and can become a complex spaghetti diagram. As an example of the usefulness of such a diagram for Gyrfalcons, I focused on one specific issue, air temperature, to illustrate the ramifications of a change in the temperature regime (Figure 4). A change in temperature (or growing degree days, GDD) can affect the choice of habitat by Gyrfalcons, the thickness and permanence of soil permafrost, which affects soil temperature and available water, which may affect prey and their food, and ultimately it affects the vegetation response, which has repercussions on fire risk. The occurrence of fire would then trigger various feedbacks to the entire system. It is a simple way to look at all known interactions in a system so that when a management strategy is discussed, its full impacts can be identified and better decisions can be made.

Climate change (for example a change in the snow/rain ratio in arctic regions) or other disturbance scenarios (increased fire risk, increased resources extraction sites) can be identified based on the caveats discussed earlier and their impacts followed through using the diagram. The future may be full of surprises but judicious use of model projections at appropriate scales should increase awareness of change and help prepare smart strategies. The conceptual model can be used to identify intervention points - elements of the system that can be manipulated - so that planners can brainstorm practical management actions at each point to help achieve the stated objective under each climate change scenario. Potential management actions are filtered by their relative feasibility and desirability, and prioritized for implementation. It is important to note that knowledge gaps can also emerge from this exercise and that monitoring further changes in the system can be a remarkably important and rewarding action before deciding on a particular management scheme. Post et al. (2009) concluded their remarks on recent climate change observations in the Arctic by saying that "foreseeing and mitigating the ecological consequences of future climate change will require more intensive, multidisciplinary monitoring of both the physical drivers of these systems and biological responses to them."

The most important item in this exercise is the collaboration between managers and experts. 


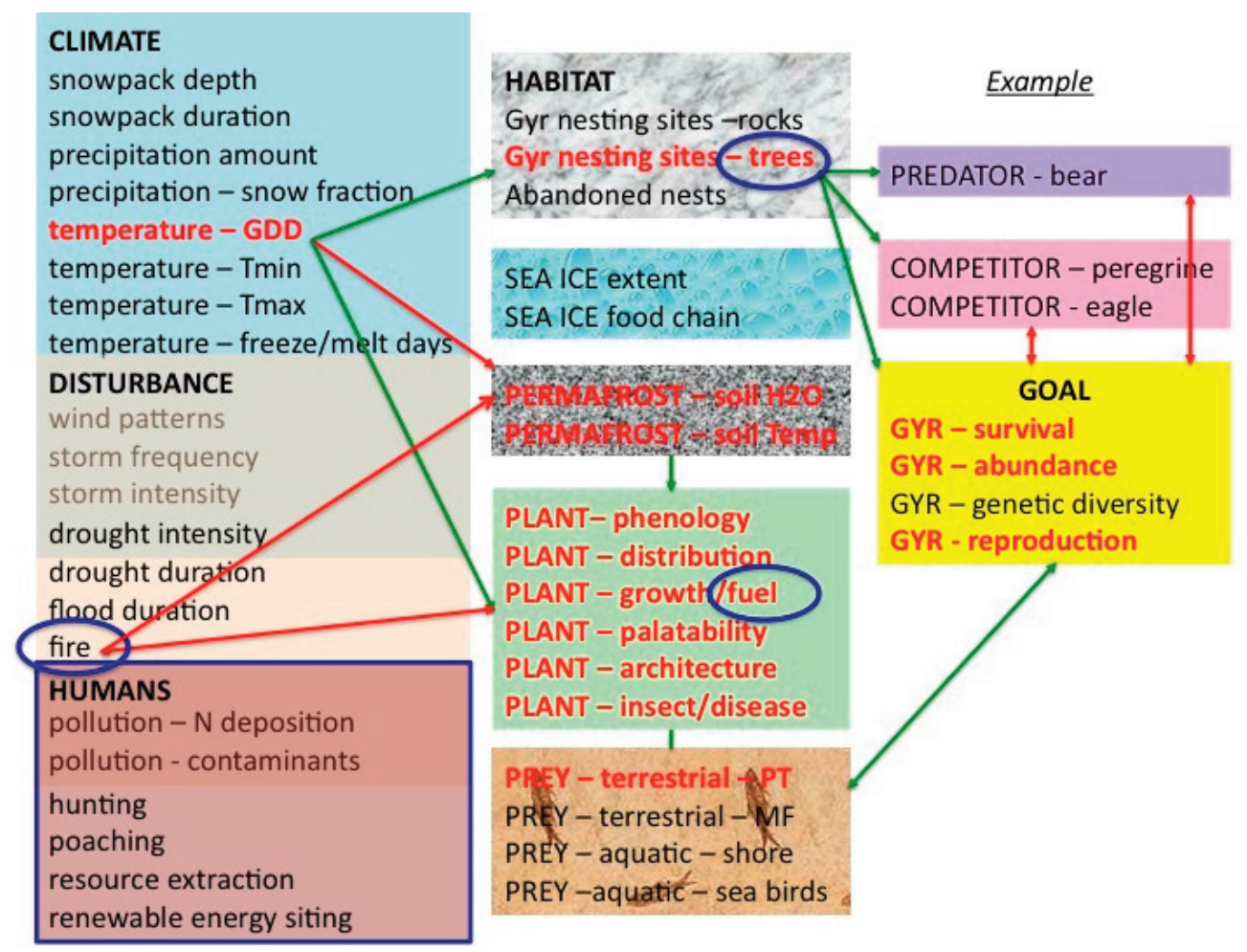

Figure 4. Diagram illustrating the interactions between various factors affecting Gyrfalcon populations in Arctic regions.

Knowledge from various disciplines and lines of work needs to be shared and all existing assumptions about the system being examined need to be transparent in order to identify the information underlying the decision-making process and justify future decisions. New tools exist to facilitate communication and sharing of relevant information. For example, Conservation Biology Institute created a web site, databasin.org, that provides conservationrelated spatial information that can be shared, manipulated, and commented on by individuals accessing the data freely on the web or by groups of interested parties for whom relevant datasets have been bookmarked and made more easily accessible through a group feature (Bachelet et al. 2011). The web site includes almost 5,000 public spatial datasets (and about
3,000 private datasets) that are being used by over 2,500 registered users (as of 31 July 2011) and a multitude of others. It is based on ArcGIS online. A Gyrfalcon group was created to facilitate such sharing of information for the participants of the conference (http://app. databasin.org/app/pages/search.jsp\#type= group \&query=gyrfalcon\&sortField=relevance \&ascending=true). The information presented at the conference can be uploaded and easily shared with all participants this way. Increasing the social capacity for awareness, understanding, and preparation for climate change or other disturbance impacts will become increasingly important as new approaches to protect biological diversity in the face of climate change are proposed and implemented. 


\section{Literature Cited}

ACKerly, D. D. 2003. Community assembly, niche conservatism, and adaptive evolution in changing environments. International Journal of Plant Sciences 164: S165-S184.

Amthor, J. S., J. M. Chen, J. S. Clein, S. E. Frolking, M. L. Goulden, R. F. GRANT, J. S. Kimball, A. W. King, A. D. McGuire, N. T. Nikolov, C. S. PotTer, S. WANG, AND S. C. Wofsy. 2001. Boreal forest $\mathrm{CO}_{2}$ exchange and evapotranspiration predicted by nine ecosystem process models: Intermodel comparisons and relationships to field measurements. Journal of Geophysical Research-Atmospheres 106:3362333648.

AraúJo, M. B., AND M. New. 2007. Ensemble forecasting of species distribution. Trends in Ecology and Evolution 22(1):42-47.

AraúJo, M. B., AND C. RahbeK. 2006. How does climate change affect biodiversity? Science 313: 1396-1397.

AMAP (ARCTIC MONITORING AND ASSESSMENT Programme). 2011. Snow, Water, Ice and Permafrost in the Arctic (SWIPA) assessment report. Executive summary available on-line at http://www.amap.no/swipa/

B AChelet, D., T. COMEndant, AND J. STRITTHOLT. 2011. Web platform for sharing spatial data and manipulating them online. EOS, Transactions American Geophysical Union 92:118-119.

B achelet, D., J. M. Lenihan, R. P. NeIlson, R. J. DRAPEK, AND T. KitTEL. 2005. Simulating the response of natural ecosystems and their fire regimes to climatic variability in Alaska. Canadian Journal of Forest Research 35:2224-2257.

B achelet, D., R. P. Neilson, J. M. Lenihan, AND R. J. DRAPEK. 2001. Climate change effects on vegetation distribution and carbon budget in the United States. Ecosystems 4:164-185.

BeCK, P. S. A., G. P. JudAY, C. Alix, V. A. BARBer, S. E. Winslow, E. E. Sousa, P. Heiser, J. D. Herriges, S. J. Goetz. 2011. Changes in forest productivity across Alaska consistent with biome shift. Ecol- ogy Letters http://dx.doi.org/10.1111/j. 1461-0248.2011.01598.x

BondeAu, A., D. W. Kicklighter, J. KAduK, AND PARTICIPANTS OF "PotSDAM '95." 1999. Comparing global models of terrestrial net primary productivity (NPP): Importance of vegetation structure on seasonal NPP estimates. Global Change Biology 5:35-45.

Clark, J. S., S. R. CARPenter, M. Barber, S. Collins, A. Dobson, J. Foley, D. Lodge, M. Pascual, R. Pielke, JR., W. Pizer, C. Pringle, W. V. Reid, K. A. Rose, O. Sala, W. H. Schlesinger, D. Wall, AND D. WEAR. 2001. Ecological forecasts: An emerging imperative. Science 293:657660.

Cramer, W., A. Bondeau, F. I. Woodward, I. C. Prentice, R. A. Betts, V. Brovkin, P. M. CoX, V. Fisher, J. Foley, A. D. Friend, C. Kucharik, M. R. Lomas, N. Ramankutty, S. Sitch, B. Smith, A. White, And C. Young-Molling. 2001. Global response of terrestrial ecosystem structure and function to $\mathrm{CO}_{2}$ and climate change: Results from six dynamic global vegetation models. Global Change Biology 7:357-373.

Cross, M. S., E. S. Zavaleta, D. B achelet, M. L. Brooks, C. A. F. EnQuist, E. Fleishman, L. Graumlich, C. R. Groves, L. Hannah, L. Hansen, G. Hayward, M. Koopman, J. J. Lawler, J. Malcolm, J. Nordgren, B. Petersen, D. Scott, S. L. Shafer, M. R. Shaw, AND G. M. TABor. 2011. The Adaptation for Conservation Targets (ACT) Framework: A tool for incorporating climate change into natural resource conservation and management. Submitted after revision to Environmental Management.

Daly, C., D. R. Conklin, And M. H. UNSWORTH. 2009. Local atmospheric decoupling in complex topography alters climate change impacts. International Journal of Climatology 30:1857-1864. http://dx.doi.org/10.1002/joc.2007 
Díez, E., C. Primo, J. A. García-Moya, J. M. GuTIÉRREZ, AND B. ORfILA. 2005. Statistical and dynamical downscaling of precipitation over Spain from DEMETER seasonal forecasts. Tellus A57:409-423.

Elith, J., C. H. Graham, R. P. Anderson, M. Dudik, S. Ferrier, A. Guisan, R. J. HiJmans, F. HuetTMANN, J. R. LeathWick, A. Lehmann, J. Li, L. G. Lohmann, B. A. Loiselle, G. Manion, G. Moritz, M. NAKAMURA, Y. NAKAZAWA, J. McC. Overton, A. T. Peterson, S. J. Phillips, K. Richardson, R. SCACHETTI-PEREIRA, R. E. SCHAPIRE, J. Soberón, S. Williams, M. S. WisZ, AND N. E. ZimmermanN. 2006. Novel methods improve prediction of species' distributions from occurrence data. Ecography 29:129-151.

Feng, S., C-H. Ho, Q. Hu, R. J. Oglesby, AND S-J. JEONG. 2011. Evaluating observed and projected future climate changes for the Arctic using the Koppen-Trewartha climate classification. Climate Dynamics. http:// dx.doi.org/10.1007/s00382-011-1020-6

Fowler, H., S. Blenkinsop, AND C. TEBAldi. 2007. Linking climate change modeling to impacts studies: Recent advances in downscaling techniques for hydrological modeling. International Journal of Climatology 27:1547-1578.

Giorgi, F., AND L. O. MEARns. 2002. Calculation of average, uncertainty range, and reliability of regional climate changes from AOGCM simulations via the "Reliability Ensemble Averaging" (REA) Method. Journal of Climate 15:1141-1158.

GLECKLER, P. J., K. E. TAYLOR, AND C. DOUTRIAUX. 2008. Performance metrics for climate models. Journal of Geophysical Research 113, D06104. http://dx.doi.org/10.1029/ 2007JD008972

Gonzalez, P., R. P. Neilson, J. M. Lenihan, AND R. J. DRAPEK. 2010. Global patterns in the vulnerability of ecosystems to vegetation shifts due to climate change. Global Ecology and Biogeography 19:755-768.

Groisman, P. Y., R. W. KNIGHT, D. R. EASTERLING, T. R. KARL, G. C. HEgerl, AND V. N. RAZUVAEV. 2005. Trends in intense precip- itation in the climate record. Journal of Climate 18:1326-1350.

IPCC (INTERgovernmental PANel FOR CliMATE Change). 2007. Contribution of Working Group I to the Fourth Assessment Report of the Intergovernmental Panel on Climate Change, 2007. S. Solomon, D. Qin, M. Manning, Z. Chen, M. Marquis, K. B. Averyt, M. Tignor, and H. L. Miller (Eds.). Cambridge University Press, Cambridge, UK and New York, New York, USA.

Klausmeyer, K. R., AND M. R. Shaw. 2009. Climate change, habitat loss, protected areas and the climate adaptation potential of species in Mediterranean ecosystems worldwide. PLoS ONE 4:e6392. http:// www.plosone.org/article/info:doi/10.1371/ journal.pone.0006392

LitTell, J. S., E. E. O’Neil, D. McKenzie, J. A. Hicke, J. A. Lutz, R. A. Norheim, AND M. M. ElSNER. 2010. Forest ecosystems, disturbance, and climatic change in Washington State, USA. Climatic Change 102:129-158.

McGuire, A. D., S. Sitch, J. S. Clein, R. DARGAVILLE, G. ESSER, J. Foley, M. HEIMANN, F. JoOs, J. KaPlan, D. W. KickLighter, R. A. Meier, J. M. Melillo, B. Moore III, I. C. Prentice, N. Ramankutty, T. Reichenau, A. Schloss, H. Tian, L. J. WILliAMS, AND U. WiTTENBERG. 2001. Carbon balance of the terrestrial biosphere in the twentieth century: Analyses of $\mathrm{CO}_{2}$, climate and land-use effects with four process-based ecosystem models. Global Biogeochemical Cycles 15:183-206.

Moss, R. H., J. A. Edmonds, K. A. Hibbard, M. R. Manning, S. K. Rose, D. P. van Vuuren, T. R. Carter, S. Emori, M. Kainuma, T. Kram, G. A. Meehl, J. F. Mitchell, N. NAKicENOVIC, K. Riahi, S. J. Smith, R. J. Stouffer, A. M. Thomson, J. P. Weyant, AND T. J. Wilbanks. 2010. The next generation of scenarios for climate change research and assessment. Nature 463(7282):747-56.

Nakicenovic, N., J. Alcamo, G. Davis, B. DE VRies, J. Fenhann, S. GafFin, K. Gregory, A. Grübler, T. Y. Jung, T. Kram, E. 
Lebre La Rovere, L. Michaelis, S. Mori, T. Morita, W. Pepper, H. Pitcher, L. Price, K. Riahi, A. Roehrl, H-H Rogner, A. SANKovski, M. Schlesinger, P. ShuKLa, S. SMith, R. SWART, S. VAn RooIJEN, N. VICTOR, AND Z. DADI. 2000. Special Report on Emissions Scenarios: A Special Report of Working Group III of the Intergovernmental Panel on Climate Change, Cambridge University Press, Cambridge, UK. http://www.grida.no/climate/ipcc/ emission/index.htm and http://sres.ciesin. org/final_data.html

Nicotra, A. B., O. K. Atkin, S. P. Bonser, A. M. Davidson, E. J. Finnegan, U. Mathesius, P. Poot, M. D. Purugganan, C. L. Richards, F. Valladares, AND M. VAN KLEUNEN. 2010. Plant phenotypic plasticity in a changing climate. Trends in Plant Science 15:684-692.

OKin, G. S., J. E. Bullard, R. L. Reynolds, J. A. C. Ballantine, K. Schepanski, M. C. Todd, J. Belnap, M. C. BADdOCK, T. E. Gill, AND M. E. Miller. 2011. Dust: Small-scale processes with global consequences. Eos (American Geophysical Union) 92:241-242.

Pandolfi, J. M., S. Connolly, D. Marshall, AND A. COHEN. 2011. Projecting coral reef futures under global warming and ocean acidification. Science 333:418-422.

PARKer, D. E. 2006. A demonstration that large-scale warming is not urban. Journal of Climate 19: 2882-2895.

Pearson, R. G., W. Thuiller, M. B. Araújo, E. Martinez, L. Brotons, C. McClean, L. Miles, P. Segurado, T. Dawson, and D. LEES. 2006. Model-based uncertainty in species range prediction. Journal of Biogeography 33:1704-1711.

Post, E., M. C. Forchhammer, S. BretHarte, T. V. Callaghan, T. R. ChrisTENSEN, B. Elberling, A. D. Fox, O. Gilg, D. S. Hik, T. T. HøYe, R. A. Ims, E. JePPESEn, D. R. Klein, J. Madsen, A. D. MCGuire, S. RYSGAARD, D. E. SCHINDLER, I. Stirling, M. P. Tamstorf, N. J. C. TYLER, R. VAN DER WAL, J. WELKER, P. A.
WoOKey, N. M. Schmidt, AND P. AAstRUP. 2009. Ecological dynamics across the Arctic associated with recent climate change. Science 325:1355-1358.

PumA, M. J., AND B. I. COOK. 2010. Effects of irrigation on global climate during the $20^{\text {th }}$ Century. Journal of Geophysical ResearchAtmospheres 115:D16120. http://dx.doi. org/10.1029/2010JD014122.

RAISANEN, J. 2007. How reliable are climate models? Tellus A 59:2-29.

Rehfeldt, G. E., N. L. Crookston, M. V. WARWELL, AND J. S. EVANS. 2006. Empirical analyses of plant-climate relationships for the western United States. International Journal of Plant Sciences 167:1123-1150.

REICHLER, T., AND J. KIM. 2008. How well do coupled models simulate today's climate? Bulletin of the American Meteorological Society 89:303-311.

RuMMUKAINEN, M. 2010. State-of-the-art with regional climate models. Wiley Interdisciplinary Reviews. Climate Change 1:82-96.

Scholze, M., W. KNorR, N. ARNell AND I. C. PRENTICE. 2006. A climate-change risk analysis for world ecosystems. Proceedings of the National Academy of Sciences 103:13116-13120.

Thorpe, A. S., and A. G. Stanley. 2011. Determining appropriate goals for restoration of imperiled communities and species. Journal of Applied Ecology 48:275-279.

Wiens, J., AND D. B ACHELET. 2010. Matching the multiple scales of conservation with the multiple scales of climate change. Conservation Biology 24(1):51-62.

Wiens, J. A., D. StRALBERGA, D. JongSOMJITA, C. A. Howella, AND M. A. SNYder. 2009. Niches, models, and climate change: Assessing the assumptions and uncertainties. Proceedings of the National Academy of Sciences 106:19729-19736.

Wilby, R. L., T. M. L. Wigley, D. Conway, P. D. Jones, B. C. Hewitson, J. Main, AND D. S. WILKS. 1998. Statistical downscaling of general circulation model output: A comparison of methods. Water Resources Research 34:2995-3008. 